\title{
Genic heterozygosity and fitness in rye populations with B chromosomes
}

\author{
C. BENITO, F. ROMERA, M. DIEZ \& A. M. FIGUEIRAS \\ Departamento de Genética, Facultad de Biologia, Universidad Complutense, 28040-Madrid, Spain
}

\begin{abstract}
Four Korean rye populations with B chromosome frequencies ranging from 15 to 55 per cent were electrophoretically analysed. The values of several components of fitness were also estimated in 1 year at a single density in plants with a different number of heterozygous loci and B chromosomes. All the fitness components decreased as the number of Bs per plant increased. A significant positive correlation between the number of heterozygous loci and both tillering and offspring was found. In addition, a significant negative correlation between the frequency of plants with Bs and the mean heterozygosity was observed. This latter relationship might be due to the high rate of selfing displayed by populations with high frequency of plants carrying Bs, leading to a low genic heterozygosity.
\end{abstract}

Keywords: B chromosomes, fitness, heterozygosity, isozymes, rye.

\section{Introduction}

B chromosomes are widely distributed in rye populations. The viability of plants with Bs does not seem to be affected, while fertility decreases when the number of Bs increases (Romera et al., 1989a). The B chromosomes have a non-Mendelian mode of transmission and tend to increase in number by non-disjunction during both male and female gametogenesis (for a review see Jones \& Rees, 1982). It has been pointed out that the pollen from rye plants with Bs successfuly fertilizes more frequently than pollen from rye plants without Bs (Puertas \& Carmona, 1976). In addition, Cruz-Pardilla et al. (1989) have studied the genetic structure and mating system of rye populations with Bs. They suggest that B chromosomes appear to promote outcrossing, at least in populations where self-fertilization is possible.

High frequencies of Bs are found in certain Korean populations. Although variation in B chromosome frequencies among these populations was found which was not related to any geographical or ecological cline, Romera et al. (1988b) found a significant negative correlation between the frequency of plants with $\mathrm{Bs}$ in these Korean populations and the mean heterozygosity for certain isozymic loci.

In this work, we have studied four Korean rye populations by means of isozyme electrophoresis to analyse the relation between the number of heterozygous loci per plant, the number of Bs per plant and also some components of fitness.

\section{Materials and methods}

Four Korean rye populations named Paldang, Gumsan 3, Gumsan 4 and Puyo, supplied by Dr Lee (Seoul National University), were analysed. The plants used in this study came directly from seeds from the original populations.

About 150 seeds per population were germinated in Petri dishes on wet filter paper at a temperature of $25 \pm 1^{\circ} \mathrm{C}$. One root per seed was cut off to determine its chromosome number. The seedlings were sown in an experimental field located at the Universidad Complutense of Madrid (40 $27^{\prime} 10^{\prime \prime} \mathrm{N}, 3^{\circ} 43^{\prime} 27^{\prime \prime} \mathrm{W}$ ) at $664 \mathrm{~m}$ a.s.l. Only wheat and rye crops have been grown in this field during the last 15 years. All the seedlings were planted at the same time (second week in November 1986) at $15-\mathrm{cm}$ intervals in rows $10 \mathrm{~cm}$ apart. Plants were harvested on the last week in June 1987. The climate is continental, characterized by cool winters and warm dry summers. The annual means for local precipitation and temperature are $456 \mathrm{~mm}$ and $14.3^{\circ} \mathrm{C}$, respectively (30-year average). At anthesis each population was covered with a thin white cotton fabric to prevent cross-pollination among plants but to allow open-pollination within each one.

Leaf isozyme genotypes were analysed using only a small part of a single leaf in each plant and their offspring were individually collected in order to estimate five components of the fitness, namely: tillering (number of tillers producing seeds), mean number of flowers per ear, mean number of seeds per ear, fertility 
of female gametes (estimated by the ratio of the number of seeds produced by the total number of flowers), and total offspring (number of seeds per plant). Guard plants were included in the analysis because their means for the five fitness parameters studied in this work were not statistically different from those exhibited by the remainder of the plants.

The isozyme systems analysed were: glutamate oxaloacetate transaminase (GOT), phosphoglucomutase (PGM), glucose phosphate isomerase (GPI), malate dehydrogenase ( $\mathrm{MDH})$, 6-phosphogluconate dehydrogenase (PGD), acid phosphatase (ACPH), esterases (EST) and peroxidases (PER). We followed the protocols of Figueiras et al. (1985). The zymogram phenotypes of these isozyme systems, the nomencla-
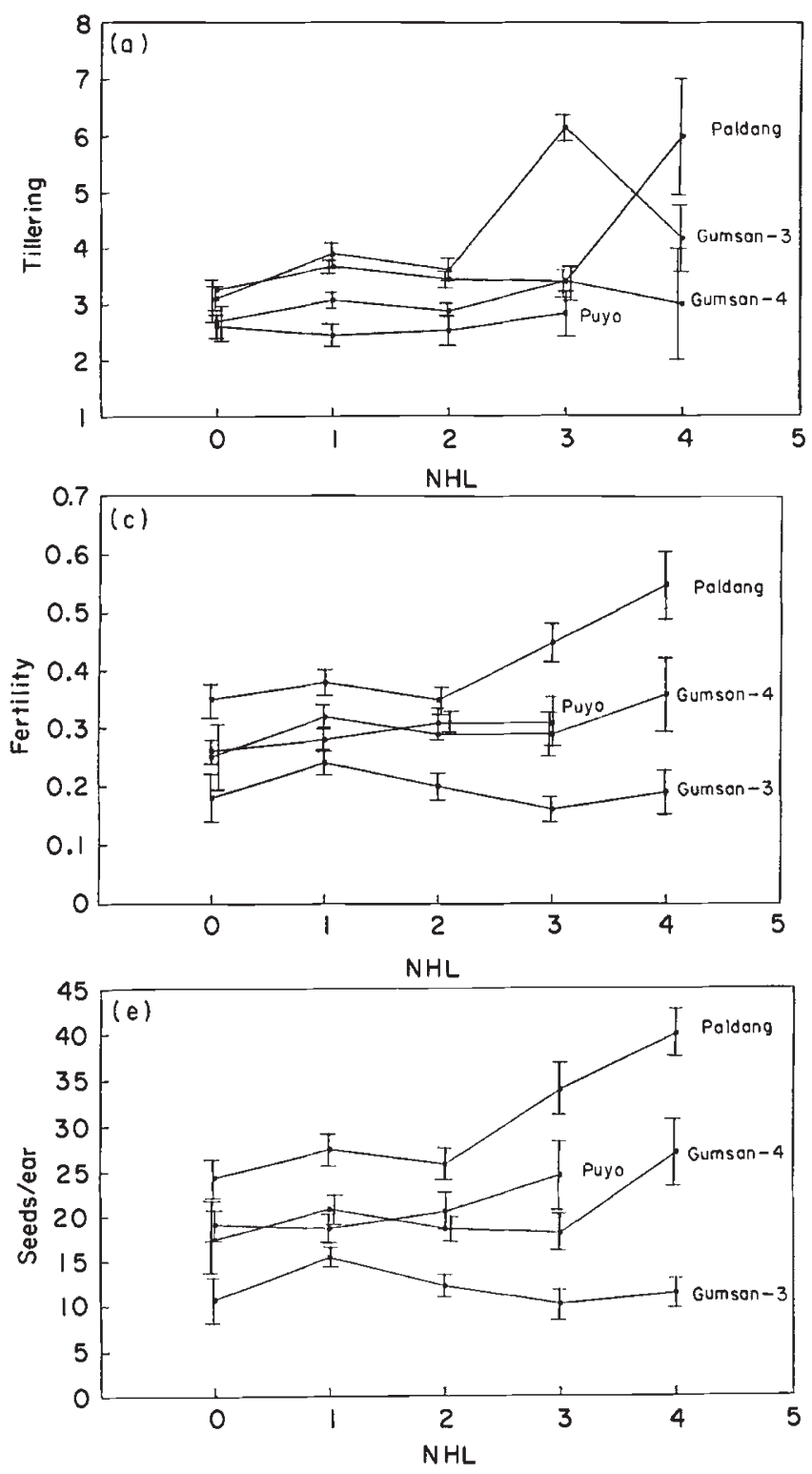

ture used and the loci chromosomal location were reported by Figueiras et al. $(1985,1991)$.

\section{Results}

The loci analysed in this work were: Got-3 (located at $3 R \mathrm{~L}$ chromosome arm), Pgm-1 (4RS), Gp1-1 (1RS), Mdh-2 (3RL), Pdg-2 (1RL), Acph (7RL), Got-1 (6RL, 7RL), Got-2 (3RL), Mdh-1 (1RL), Pgd-1 (4RL, 6RL), Per-1 (1RL) and Per-5 (2RS). The last six loci were invariant. Other peroxidase $(P e r)$ and esterase $(E s t)$ loci are polymorphic for null alleles and it is not possible to distinguish heterozygous from homozygous plants.

Figure 1 shows the means of the five components of fitness in relation to the number of heterozygous loci
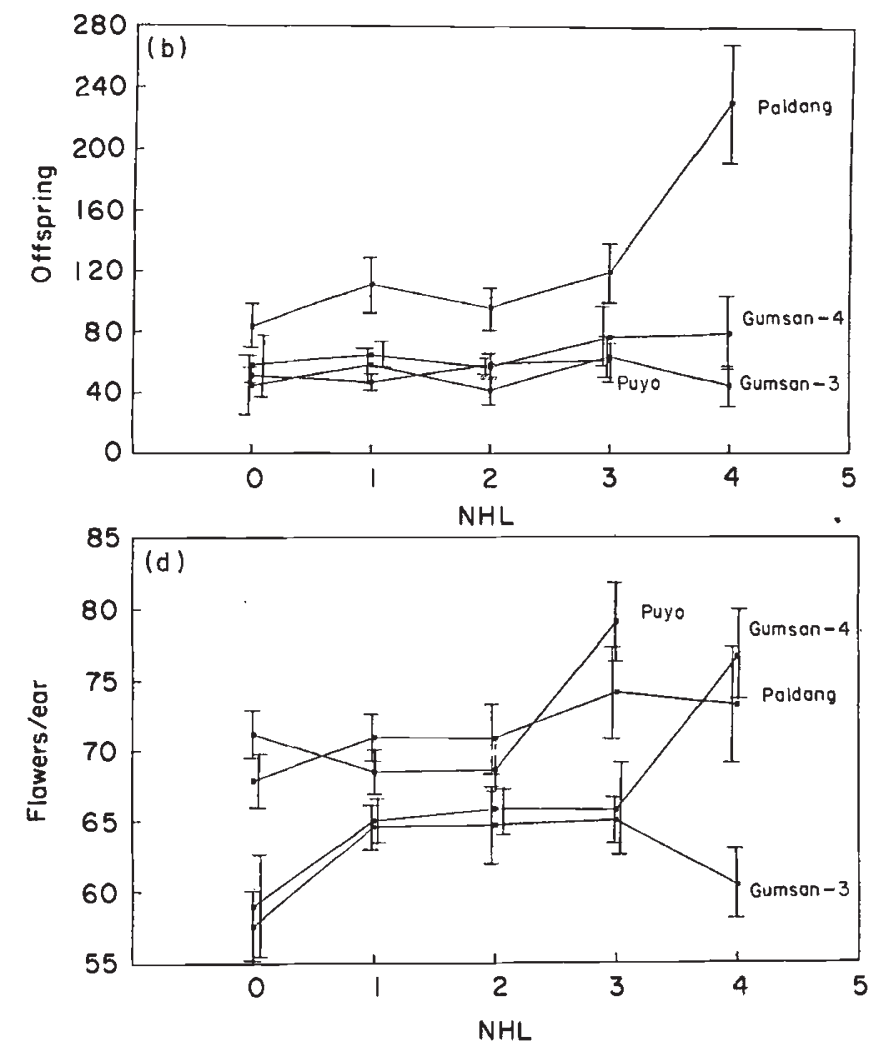

Fig. 1 Mean of five fitness components for the number of heterozygous loci per plant (NHL) in four rye populations with B chromosomes (Palgang, Gumsan-3, Gumsan-4 and Puyo). (a) Tillering and NHL, (b) offspring and NHL, (c) fertility and NHL, (d) flowers/ear, (e) seeds/ear/and NHL. 
per plant in the four populations analysed (Paldang, Gumsan 3, Gumsan 4 and Puyo). The maximum number of heterozygous loci per plant was three in the Puyo population but four in the other three populations. The four populations studied show similar behaviour: an increase in tillering and total offspring is observed when the number of heterozygous loci per plant increases.

The percentages of plants with Bs were 23, 15, 17, and 51 in Paldang, Gumsan-3, Gumsan-4 and Puyo populations, respectively. The mean heterozygosity in these populations are $0.24,0.28,0.28$ and 0.12 , respectively.

Table 1 shows the relationships among the number of heterozygous loci per plant and the five fitness components. In this case we have used the pooled data for the four populations analysed; an increase in tillering and offspring as the number of heterozygous loci per plant increases can again be observed.

Linear regressions among the fitness components, number of B chromosomes per plant and number of heterozygous loci per plant were carried out on pooled data and are shown in Table 2 . Three main conclusions were obtained, namely: (i) the five fitness components all decreased as the number of Bs increased, (ii) there is weak negative correlation between the number of heterozygous loci and the number of Bs per plant, and (iii) there is positive correlation between the number of heterozygous loci per plant and both tillering and offspring. Because the Puyo population might have distorted the results we reran the analysis with pooled data from the three populations that showed a low percentage of plants with Bs and a similar mean heterozygosity (Paldang, Gumsan 3 and Gumsan 4). Here too tillering and total offspring increase as the number of heterozygous loci per plant increases.

The effect of each individual isozyme locus on the five fitness components studies was analysed (Table 3 ). We found no significant positive or negative associations between specific isozyme loci and the five components. In spite of this, plants heterozygous for the loci analysed produced more fertile tillers and more seeds per plant than plants homozygous for the same loci (except for the Acph locus).

Table 1 Mean of the five components and standard errors for the number of heterozygous loci per plant with the pooled data of the four populations studied

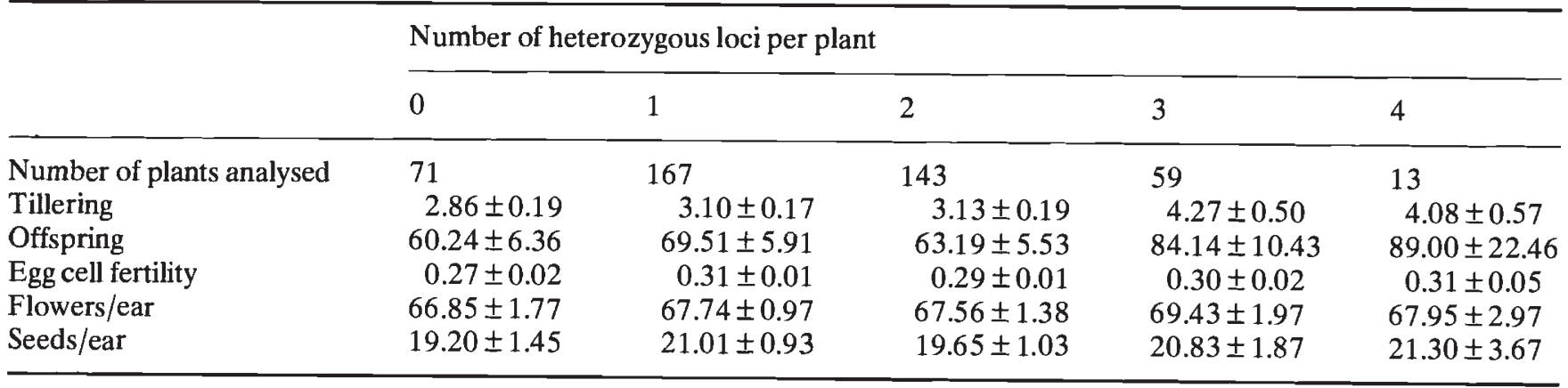

Table 2 Linear regression between the five fitness components with the pooled data of the four populations studied. The slopes of the equations (above diagonal) and levels of significance (below diagonal)

\begin{tabular}{|c|c|c|c|c|c|c|c|}
\hline & $\begin{array}{l}\text { Number of } \\
\text { heterozygous } \\
\text { loci }\end{array}$ & $\begin{array}{l}\text { Number of B } \\
\text { chromosomes } \\
\text { per plant }\end{array}$ & Tillering & Offspring & $\begin{array}{l}\text { Egg cell } \\
\text { fertility }\end{array}$ & Flowers/ear & Seeds/ear \\
\hline $\begin{array}{l}\text { Number of heterozygous } \\
\text { loci per plant }\end{array}$ & & -0.103 & 0.380 & 6.980 & 0.004 & 0.592 & 0.388 \\
\hline $\begin{array}{l}\text { Number of B chromosomes } \\
\text { per plant }\end{array}$ & * & & -0.253 & -11.945 & -0.032 & -0.423 & -2.373 \\
\hline Tillering & $* * *$ & * & & 19.763 & 0.003 & 1.085 & 0.461 \\
\hline Offspring & $*$ & $*$ & $* * *$ & & 0.001 & 0.069 & 0.112 \\
\hline Egg cell fertility & - & $* * *$ & - & *** & & 10.616 & 69.319 \\
\hline Flowers/ear & - & $*$ & $* * *$ & $* * *$ & $*$ & & 0.369 \\
\hline Seeds/ear & - & $* * *$ & - & $* * *$ & $* * *$ & $* * *$ & \\
\hline
\end{tabular}

- Plant analysed: 453 ; - Not significant slope: $P>0.05 ;{ }^{*} P<0.05 ;{ }^{* * *} P<0.001$. 
Table 3 Mean of the five fitness components and standard errors with the pooled data of the four populations studied for each isozyme genotype

\begin{tabular}{|c|c|c|c|c|c|c|c|c|c|c|c|c|}
\hline & \multicolumn{2}{|l|}{ Got-3 } & \multicolumn{2}{|l|}{$P g m-1$} & \multicolumn{2}{|l|}{ Gpi-1 } & \multicolumn{2}{|l|}{$M d h-2$} & \multicolumn{2}{|l|}{$P d g-2$} & \multicolumn{2}{|l|}{ Acph } \\
\hline & Het. & Hom. & Het. & Hom. & Het. & Hom. & Het. & Hom. & Het. & Hom. & Het. & Hom. \\
\hline$n$ & 81 & 372 & 115 & 338 & 192 & 261 & 76 & 377 & 182 & 271 & 35 & 418 \\
\hline$T$ & $\begin{array}{r}3.22 \\
\pm 0.20\end{array}$ & $\begin{array}{r}3.26 \\
\pm 0.13\end{array}$ & $\begin{array}{r}3.65 \\
\pm 0.24\end{array}$ & $\begin{array}{r}3.12 \\
\pm 0.13\end{array}$ & $\begin{array}{r}3.51 \\
\pm 0.20\end{array}$ & $\begin{array}{r}3.07 \\
\pm 0.13\end{array}$ & $\begin{array}{r}3.78 \\
\pm 0.37\end{array}$ & $\begin{array}{r}3.15 \\
\pm 0.11\end{array}$ & $\begin{array}{r}3.53 \\
\pm 0.22\end{array}$ & $\begin{array}{r}3.07 \\
\pm 0.12\end{array}$ & $\begin{array}{r}3.03 \\
\pm 0.41\end{array}$ & $\begin{array}{r}3.28 \\
\pm 0.12\end{array}$ \\
\hline$O$ & $\begin{array}{r}73.74 \\
\pm 7.66\end{array}$ & $\begin{array}{r}67.86 \\
\pm 3.72\end{array}$ & $\begin{array}{r}71.82 \\
\pm 5.81\end{array}$ & $\begin{array}{r}67.92 \\
\pm 4.03\end{array}$ & $\begin{array}{r}75.91 \\
\pm 6.30\end{array}$ & $\begin{array}{r}63.76 \\
\pm 3.49\end{array}$ & $\begin{array}{r}76.13 \\
\pm 7.85\end{array}$ & $\begin{array}{r}67.46 \\
\pm 3.70\end{array}$ & $\begin{array}{r}74.21 \\
\pm 5.65\end{array}$ & $\begin{array}{r}65.35 \\
\pm 4.11\end{array}$ & $\begin{array}{r}56.09 \\
+10.99\end{array}$ & $\begin{array}{r}69.99 \\
\pm 3.51\end{array}$ \\
\hline$E$ & $\begin{array}{r}0.30 \\
\pm 0.02\end{array}$ & $\begin{array}{r}0.28 \\
\pm 0.01\end{array}$ & $\begin{array}{r}0.30 \\
\pm 0.02\end{array}$ & $\begin{array}{r}0.30 \\
\pm 0.01\end{array}$ & $\begin{array}{r}0.30 \\
\pm 0.01\end{array}$ & $\begin{array}{r}0.29 \\
\pm 0.01\end{array}$ & $\begin{array}{r}0.31 \\
\pm 0.02\end{array}$ & $\begin{array}{r}0.29 \\
\pm 0.01\end{array}$ & $\begin{array}{r}0.30 \\
\pm 0.01\end{array}$ & $\begin{array}{r}0.29 \\
\pm 0.01\end{array}$ & $\begin{array}{r}0.23 \\
\pm 0.03\end{array}$ & $\begin{array}{r}0.30 \\
\pm 0.01\end{array}$ \\
\hline$F$ & $\begin{array}{r}68.73 \\
\pm 1.64\end{array}$ & $\begin{array}{r}67.61 \\
\pm 0.75\end{array}$ & $\begin{array}{r}68.89 \\
\pm 1.28\end{array}$ & $\begin{array}{r}67.44 \\
\pm 0.80\end{array}$ & $\begin{array}{r}68.30 \\
\pm 1.04\end{array}$ & $\begin{array}{r}67.44 \\
\pm 0.91\end{array}$ & $\begin{array}{r}66.80 \\
\pm 1.65\end{array}$ & $\begin{array}{r}68.01 \\
\pm 0.75\end{array}$ & $\begin{array}{r}68.52 \\
\pm 1.13\end{array}$ & $\begin{array}{r}67.33 \\
\pm 0.85\end{array}$ & $\begin{array}{r}65.97 \\
\pm 3.32\end{array}$ & $\begin{array}{r}67.96 \\
\pm 0.69\end{array}$ \\
\hline$S$ & $\begin{array}{r}21.23 \\
\pm 1.43\end{array}$ & $\begin{array}{r}20.14 \\
\pm 0.64\end{array}$ & $\begin{array}{r}20.42 \\
\pm 1.16\end{array}$ & $\begin{array}{r}20.31 \\
\pm 0.68\end{array}$ & $\begin{array}{r}21.03 \\
\pm 0.97\end{array}$ & $\begin{array}{r}19.82 \\
\pm 0.72\end{array}$ & $\begin{array}{r}20.94 \\
\pm 1.42\end{array}$ & $\begin{array}{r}20.21 \\
\pm 0.65\end{array}$ & $\begin{array}{r}20.66 \\
\pm 0.94\end{array}$ & $\begin{array}{r}20.11 \\
\pm 0.75\end{array}$ & $\begin{array}{r}15.75 \\
\pm 2.14\end{array}$ & $\begin{array}{r}20.72 \\
\pm 0.61\end{array}$ \\
\hline
\end{tabular}

$T=$ tillering; $O=$ offspring (seeds per plant); $E=$ egg cell fertility; $F=$ flowers/ear; $S=$ seeds/ear. Het. = heterozygous plants; Hom. $=$ homozygous plants; $n=$ number of plants analysed.

\section{Discussion}

When Romera et al. (1989a) analysed the same four populations, they found that B chromosomes did not affect viability, while fertility (seeds per plant, eggcell fertility, seeds/ear, flowers/ear) decreased as the number of Bs increased. They also found that the percentage of polymorphic loci was higher in the populations with a low frequency of plants with Bs than in populations with a high frequency of plants with Bs (Romera et al., 1989b). Our results agree with all these previous data.

The Puyo population showed a maximum of three polymorphic loci per plant and a low mean heterozygosity. In the four populations used in this work the populations with a low frequency of plants with Bs showed a higher mean heterozygosity (Fig. 1).

We observed a significant negative correlation between the number of $B$ s per plant and the number of heterozygous loci per plant (Table 2) when the pooled data from the four populations were analysed. However, this correlation was not significant when only the data of Paldang, Gumsan 3 and Gumsan 4 were used. This is because Puyo has a very high frequency of plants with Bs ( 51 per cent) and a much lower mean heterozygosity $(0.12)$ than the other three populations examined. To avoid spurious relationships arising from this, we studied the correlations between the number of heterozygous loci and the five components of the fitness both in all four populations combined and also in the three that have a similar mean heterozygosity.
The plants with a higher number of heterozygous loci produced more fertile tillers and also more seeds per plant than the plants with few heterozygous loci (Tables 1 and 2). These relations were significant when the pooled data of the four populations were analysed. Similar results were found when we studied the pooled data of Paldang, Gumsan 3 and Gumsan 4 populations. In this case, a significant and positive correlation was found between the number of heterozygous loci per plant and both tillering and the mean number of flowers per ear, but not between the number of heterozygous loci and seed per plant. The positive correlation between the number of heterozygous loci and tillering was also found individually in the Paldang, Gumsan 3 and Gumsan 4 populations.

The isozyme loci analysed in this work are located on A chromosomes (Figueiras et al., 1985) and we do not expect a direct correlation between these loci and the B chromosomes. When we analysed the effect of individual loci in the different components of the fitness studied (Table 3) we observed no correlation between specific loci and either tillering and seeds per plant. Probably, the plants with few heterozygous loci are more inbred than the plants with many heterozygous loci, so we are estimating the level of the individual heterozygosity of a plant.

The JNK population has a high percentage of plants with Bs (65 per cent), a very high rate of selfing, close to 35 per cent (Cruz-Pardilla et al., 1989) and a mean heterozygosity for isozyme loci of 0.14 (Figueiras $e t$ al., 1988). Cruz-Pardilla et al. (1989) suggest that B 
chromosomes influence the genetic structure of rye populations by promoting cross-pollination among different plants.

Populations with a high rate of selfing (e.g. Puyo or JNK) may have a high frequency of plants with B chromosomes and low mean heterozygosity. The high rate of selfing and the non-Mendelian transmission of B chromosomes could explain the high frequency of B chromosomes per plant observed in these populations. These populations also have fewer polymorphic loci and mean heterozygosity.

The main cause of selfing in JNK seems to be due to the presence of self-fertility genes because 64 per cent of the bagged plants without Bs showed a fertility higher than 10 per cent (Cruz-Pardilla et al., 1989). Another possible explanation pointed out by these authors is the influence of Bs on the genetic system controlling incompatibility but there is no direct experimental evidence for this. The results obtained in our work suggest that the populations with a high frequency of B chromosomes probably have a high rate of selfing and as a consequence have a low percentage of polymorphic loci and a low mean heterozygosity. Zečević \& Paunović (1967), and Zečević \& Tucić (1973), who studied rye populations with Bs from Yugoslavia, found an increase in the self-fertility in the rye populations from the north-western part of Yugoslavia (Slovenia) towards the south-eastern part (Macedonia) which corresponds to the increase in the number of plants with supernumerary chromosomes.

Puertas et al. (1989) proposed a model to relate the proportion of self-pollination $(S)$ and the proportion of plants to Bs $(B)$. According to this model, when the frequency of $\mathrm{Bs}$ increases selfing must decrease. For example: for $B=0.50, S<0.33$ and for $B=0.66$, $S<0.02$. The estimations of this model are in disagreement with the observed data in the JNK population by Cruz-Pardilla et al. (1989), being $B=0.65$ and $S=0.35$. This model supposes the same $S$ for all the plants studied, but Cruz-Pardilla et al. (1989) found that the subpopulation of plants with Bs shows that $S=0.20$ whereas for the subpopulation of plants without Bs $S=0.45$.

Evidence for correlations between fitness traits and heterozygosity has been found in several animal and plant species (for a review, see Zouros \& Foltz, 1987). In plants, growth rate is positively associated with allelic isozyme heterozygosity in Liatris cylindracea, pitch pine and quaking aspen (Schall \& Levin, 1976; Mitton \& Grant, 1980; Ledig et al., 1983). Among invertebrates, the best evidence for this association comes from species of mollusc, American oyster (Crassostrea virginica) and blue mussel (Mytilus edulis) Koehn \& Gaffney, 1984; Zouros \& Foltz, 1984). In addition, associations between heterozygosity and viability, and heterozygosity and fertility have been described in plants, invertebrates and vertebrates (Zouros \& Foltz, 1987). We have found associations between heterozygosity and tillering, and also between heterozygosity and seeds per plant in the four Korean rye populations. In addition, we have observed similar results in a rye population that are polymorphic for reciprocal translocations (A. M. Figueiras et al. unpublished data). Therefore, these data suggest the probability that B chromosome numbers are not directly related to genic heterozygosity. However, the Korean rye populations, with a low frequency of plants with Bs, showed a higher mean heterozygosity. The main cause of this association is not known for certain, but we suggest that populations with a high rate of selfing and with a low heterozygosity present a high frequency of plants with Bs.

\section{Acknowledgements}

This work was supported by a grant (PB87-0087) from the CICYT of Spain. We would like to thank the Instituto Nacional de Meteorología for the climatic data.

\section{References}

CRUZ-PARDILlA, M., VENCES, F. J., GARCIA, P. AND PEREZ DE LA VEGA, M. 1989. The effect of B chromosomes on outcrossing rate in a population of rye (Secale cereale $\mathrm{L}$.). Heredity, 62, 319-325.

FIGUEIRAS, A. M., ELORRIETA, M. A. AND BENITO, C. 1991. Genetic and cytogenetic maps of chromosomes $1 R, 4 R$ and $7 R$ in cultivated rye (Secale cereale). Genome, 34, 681-685.

FIGUEIRAS, A. M., GONZALEZ-JAEN, M. T., CANDELA, M. AND BENITO, C. 1988. Genic heterozygosity maintained by chromosomal interchanges in rye. Heredity, 60, 47-54.

FIGUEIRAS, A. M., GONZALEZ-JAEN, M. T., SALINAS, J. AND BENITO, C. 1985. Association of isozymes with a reciprocal translocation in cultivated rye (Secale cereale L.). Genetics, 109, 177-193.

JONES, R. N. AND REES, H. 1982. B Chromosomes. Academic Press, London.

KOEHN, R. K. AND GAFFNEY, P. M. 1984. Genetic heterozygosity and growth rate in Mytilus edulis. Mar. Biol., 82, 1-7.

LEDIG, F. T., GURIES, R. P. AND BONEFELD, B. A. 1983. The relation of growth to heterozygosity in pitch pine. Evolution, 37, 1227-1238.

MITTON, J. B. AND GRANT, M. c. 1980 . Observations on the ecology and evolution of quakin aspen Populus termuloides, in the Colorado front range. Am. J. Bot, 67, 202-209.

PUERTAS, M. J. AND CARMONA, R. 1976. Greater ability of pollen tube growth in rye plants with $2 \mathrm{~B}$ chromosomes. Theor. Appl. Genet., 47, 41-43. 
PUERTAS, M. J., RAMIREZ, A. AND BAEZA, F. 1989. The transmission of B chromosomes in Secale cereale and Secale vavilovii populations. II. Dynamics of populations. Heredity, 58, 81-85.

ROMERA, F., VEGA, J. M., DIEZ, M. AND PUERTAS, M. J. 1989a. B chromosome polymorphism in Korean rye populations. Heredity, 62, 117-121.

ROMERA, F, VEGA, J. M., DIEZ, M. AND PUERTAS, M. J. 1989b. Polymorphism for isozyme loci in relation with the polymorphism for B chromosomes in rye populations. Ann. Aula Dei, 18, (1-2), 79-88.

SCHALL, B. A. AND LEVIN, D. A. 1976. The demographic genetics of Liatris cylindracea Michx. (Compositae). Am. Nat., 110, 191-206.
ZEČEVIC, L. AND PAUNOVIC, D. 1967. B chromosome frequency in Yugoslav rye populations. Biol. Plantarum (Praha), 9, 205-211.

ZEČEVIC, L. AND TUCIC, B. 1973. Inbreeding effect in Yugoslav rye populations. Arch. Biol. nauka (Beograd), 25, 25-34.

zouRos, E. AND FOLTZ, D. w. 1984. Minimal selection requirements for the correlation between heterozygosity and growth, and for the deficiency of heterozygotes, in oyster populations. Dev. Genet., 4, 393-405.

zouros, E. AND FOLTZ, D. W. 1987. The use of allelic isozyme variation for the study of heterosis. In: Rattazzi, M. C., Scandalios, J. G. and Whitt, G. S. (eds) Isozymes. Current Topics in Biological and Medical Research. vol. 13, A. R. Liss, New York, pp. 1-59. 